\title{
RECENT DEVELOPMENTS IN EARTHQUAKE GEOTECHNICAL ENGINEERING
}

\author{
M J Pender ${ }^{1}$
}

\begin{abstract}
SUMMARY
Progress in earthquake geotechnical engineering in the past 10 to 12 years is reviewed. Developments in understanding foundation behaviour and also liquefaction are described briefly. It is explained that perhaps the greatest advance in the period is the interpretation of the substantial amount of site response data which has come to hand. This clarifies earlier controversy about the contribution of nonlinear soil behaviour to site response. Findings show that it is possible for stiff soil sites to behave in a linear manner for quite large peak ground accelerations but for softer soils significant nonlinear response has been inferred using a number of different approaches.
\end{abstract}

\section{INTRODUCTION}

The title of this keynote panel session is linked to the $10^{\text {th }}$ anniversary of the Edgecumbe earthquake of March 1997. However, to review recent progress in earthquake geotechnical engineering the 1985 Michoacan earthquake, and particularly its effect on Mexico City, is a better place to start because this event is the first in a series of major earthquakes all of which have contributed much to geotechnical knowledge or which have prompted important investigations. The earthquakes in this sequence are Michoacan (1985), Edgecumbe (1987), Armenia (1988), Loma Prieta (1989), Newcastle (1989), Philippines (1990), Costa Rica (1991), Hokkaido (Hokkaido Nansei-Oki) (1993), Northridge (1994), and Kobe (Hyogoken Nanbu) (1995). From the geotechncial viewpoint, then, a better decade is 1985 to 1995 , Mexico City to Kobe, rather than the 10 years since Edgecumbe.

The aftermath of all earthquakes provides much important information about types of damage etc. Reflection on this provides insight into how design and construction should proceed to maximise earthquake resistance and also yields evidence of those practices which seem to have resulted in satisfactory performance. In addition, though, some places at which earthquakes occur, or at which earthquake waves cause severe damage, are well instrumented so that a number of records of the earthquake ground motion are obtained. It is the availability of these recorded motions that has been the greatest stimulus for the new understanding reached in the last decade or so. Those events which have provided this quality of information are Michoacan, Loma Prieta, Northridge, and Kobe. Several of the other earthquakes yielded a small number of recordings which provide some baseline information, for example the recordings on the Matahina dam during the Edgecumbe earthquake, but not the coverage that enables one to gain insight into regional variations.

\footnotetext{
'Department Civil and Resource Engineering

University of Auckland, (Fellow).
}

This paper compliments, and in some respects updates, the material presented by Pender [49] in a 1995 Keynote address to the Pacific Conference on Earthquake Engineering. Another recent brief review of similar scope is that of Lo et al [34]. Set out below are brief comments about advances in understanding of liquefaction and ground settlement, the performance of shallow foundations in saturated clay and sand, the performance of deep foundations, the response of retaining structures, the behaviour of slopes, and the performance of earth dams. However, it is in the area of site response that the most significant advances have occurred and these are due almost entirely to the large amount of ground motion data that was obtained from the four earthquakes mentioned above.

\section{SITE EFFECTS AND NONLINEAR SOIL RESPONSE}

Site effects, that is the way in which an incoming earthquake motion is modified by the near surface soil layers at a site, have been of great interest for a considerable time. There was some polarisation between the seismological and geotechnical communities with the first group concentrating on linear response and the latter expecting nonlinear soil behaviour to be significant for large peak ground accelerations. Earlier site observations tended to support linear response. However, the sites which supported linear behaviour were such that one would not have expected other than linear behaviour as the soils present were so stiff, Pender [47].

In NZ, important work has been done in the Wellington area on microzoning, comparison of earthquake records from the various instrument sites in the region, as well as defining the ground conditions at instrument sites, [27, 41, 59, 64].

\section{Mexico City and the Michoacan earthquake}

Mexico City is located several hundred $\mathrm{km}$ from the epicentre of the Michoacan earthquake. Thus the incoming rock motions at Mexico City were rather weak. However the damage at Mexico City was very severe because, under a considerable portion of 
the city, soils amplified the incoming rock motion considerably and consequently the PGA at the ground surface was large. The explanation for this was primarily that the soils at Mexico City behave in a linear manner with little damping to quite large shear strains, and secondly, that the predominant frequency of the incoming rock motion was quite close to the natural period of the soil deposit at Mexico City, thus causing resonance. It is correct to point out that the soils at Mexico City are probably unique, Whitman [68], but even so much has been learned from what happened there.

The primary lesson is that clays with a high plasticity index behave in a linear, or near linear manner, with little damping over a much larger shear strain range than soils of low plasticity. Earlier expectations were that all soils had similar relations for the variation of shear modulus and damping ratio with shear strain. The second lesson is that soft soils distant from the earthquake will show amplification because the peak ground acceleration of the incoming rock motion will then be low and likely to excite the soil profile in an elastic manner. The Mexico City recorded motions thus lent support to the view that soil behaviour in situ will be linear (hence the counter argument that Mexico City soils may be unique).

\section{Loma Prieta}

The Loma Prieta earthquake also provided many ground motion records. Several of these were in the San Francisco area up to $100 \mathrm{~km}$ or more from the epicentre. Behaviour similar to that at Mexico City was apparent in parts of Oakland where the ground response was very different for different ground conditions; the soft San Francisco Bay mud experiencing considerably greater peak ground accelerations than the firmer alluvium which in turn were greater than those on rock outcrops.

Another aspect of the recorded ground motions from the Loma Prieta earthquake was that the peak ground accelerations recorded in the San Hose area were rather less than those in San Francisco and Oakland which, although more distant from the epicentre, were on similar ground. This was subsequently traced to transmission path effects, Bolt [7].

Most significant from the site response viewpoint were recordings on a rock outcrop at Yerba Buena Island and at the surface of a layer of saturated sandy fill nearby at Treasure Island. Recordings for the main shock had a PGA of about 0.06 $\mathrm{g}$ at the rock site and $0.16 \mathrm{~g}$ at the surface of the nearby fill. Aftershock records revealed much higher relative amplification between the two sites, Jarpe et al [32] and Darragh et al [19]. This confirms the expectation that nonlinear behaviour would be more apparent for higher ground acceleration.

\section{Loma Prieta and Northridge}

The large number of earthquake records gathered for both the Loma Prieta and Northridge earthquakes do not give a simple indication of nonlinear soil behaviour. The motion at any site depends on the soil conditions beneath the instrument as well as path followed by the earthquake motion in getting to the site and, in general, records are available only for the ground surface. In the case of the 1971 San Fernando earthquake Berrill [6] found little evidence for nonlinear soil behaviour in the Los Angeles region. This same conclusion has been reached for the Northridge event, although Chin and Aki [17] have developed a way of generating synthetic ground motion records and then comparing these with the observed to reveal some nonlinear effects in the Northridge earthquake. Aki et al $[1,2,13]$ used a different technique for isolating near source nonlinearity from the Loma Prieta records. Durward et al [21] have used yet another technique to uncover nonlinear effects in the 1979 Imperial Valley earthquake records.

\section{Northridge and Kobe directional effects}

Another feature of the Northridge earthquake, also shared by Kobe, is a strong directional effect. Somerville [58] shows how for Northridge the response spectrum for recorded motions is more severe in the direction of the fault rupture than in directions transverse to the fault. Similarly, at Kobe a most unusual feature of the damage pattern was the narrow zone into which the damage is concentrated. This once again seems to be related to the direction of propagation of the earthquake motion.

\section{Down hole records}

By far the most convincing evidence of nonlinear soil behaviour during earthquake shaking comes from vertical arrays of instruments. Having simultaneous records at various depths in the soil profile means that the soil response itself can be investigated and the difficulties of comparing different sites are eliminated. Information from the Lotung site in Taiwan is reported in $[5,16,22,35,70]$ and Japanese data appears in $[29,56$, 63]. The analysis of the downhole data has been done in two ways. In one shear wave velocity profiles are used to match the response, the shear wave velocities decreasing as the level of shaking increases. In the other the acceleration data are processed to give shear strains and in situ shear modulus and damping curves

In summary then, the decade from 1985 to 1995 saw the gradual emergence of convincing evidence of nonlinear soil behaviour during earthquake shaking. The current picture that has emerged is more complex than the previous one in that the extent of linear behaviour depends on the plasticity index of the soil. The extremely unusual soils of Mexico City might suggest that this problem will not be of widespread concern. However, the fact that more typical soils, such as San Francisco Bay Mud, also exhibit the tendency to linear behaviour does suggest that the problem is of general concern for cohesive soils. Thus there is now a renewed interest in the testing of soils to establish site specific details of shear strain dependent stiffness and damping. Nevertheless, nonlinearity has been demonstrated, although soil profiles with nonlinear response may still amplify incoming rock motions but to a lesser extent than a linear profile.

\section{Site response for design analysis}

What is the significance of these conclusions for design levels of shaking for structural and foundation design? An intense research effort has resulted in suggestions for a new set of definitions of soil profiles and site factors that depend on the level of ground shaking and the period of the site, Martin and Dobry [37] and Borcherdt [8,10]. It is of interest that Borcherdt [9] reports that these factors have the ability to handle the features observed from Kobe, so the general methodology might be more widely applicable than just the revision of the Uniform Building Code for which it was developed. One deficiency of this approach is that it is not based on uniform risk principles. 
Secondly, the directivity effects observed in the Northridge event are presumably of some interest to us in NZ, as, if a major earthquake occurs in Wellington by strike-slip movement along the Wellington fault, shaking in the direction of the fault can be expected to be different from that transverse. These effects are dependent on the frequency, McVerry [73].

\section{LIQUEFACTION AND SURFACE SETTLEMENT}

\section{Liquefaction}

Liquefaction has been a significant aspect of the damage in the Edgecumbe, Loma Prieta, Philippines, Hokkaido, and Kobe earthquakes. Although the occurrence of liquefaction in these earthquakes provided much additional evidence about the process and the type of damage, there were few surprises, particularly once the site details were known.

The emphasis has moved from the prediction of liquefaction onto consideration of the amount of residual deformation from lateral spreading for sites having a sloping ground surface, as even rather gentle slopes are susceptible to movement if liquefaction occurs, or for which there is little lateral restraint such as adjacent to rivers, lakes and harbours. To date this work has focused on gathering field data and computational approaches.

Part of the difficulty with liquefaction studies lies in the sheer complexity of the stress-strain behaviour of saturated sand under cyclic loading. During the decade a number of models have been proposed which model cyclic stress-strain behaviour and pore water pressure build-up. Some of these are very complex but that of Byrne [14] uses SPT data for generating the input and so has potential for practical application.

As with site response, an important source of insight is information gained from downhole arrays of instruments. Examples are given by Iai [29] for a dense sand profile and by Sato et el [56] for profiles in Kobe.

Centrifuge studies of shallow foundations on saturated sand reveal that the greatest pore pressures are generated to the side of the foundation and not directly beneath, Liu and Dobry [33]. This confirms observations like those gained after the Niigata earthquake in which the well-known apartment buildings did not tilt until after the end of the shaking, suggesting that the lateral migration of large pore water pressures reduces the bearing capacity of the sand. An interesting numerical study of this phenomenon and of the effectiveness of a barrier consisting of sheet piling is reported by Zheng et al [71]. The authors used a finite element programme incorporating a sophisticated constitutive model for saturated sand to demonstrate the effectiveness of a ring of sheet piling at the periphery of the circular storage tank. The computations showed that the sheet piling prevented the lateral migration of pore water pressure beneath the tank

Once again these liquefaction events have emphasised the vulnerability of harbour facilities and underground services, Werner and Dickenson [67].
On the practical side, some useful comparative information has emerged about the effectiveness of various ground improvement methods in Port Island in Kobe. Various sections of this artificial island were treated with different methods of improvement. The results are presented by Yasuda [69]. Also prepared by the Japanese is a substantial manual setting out various practices for ground improvement to prevent liquefaction or to reduce liquefaction effects. An English translation of this document is in preparation. In addition, Technical Committee 4 of the International Society for Soil Mechanics and Foundation Engineering has prepared a manual for the zonation of seismic hazards [61].

\section{Surface settlement}

Dry sands do not liquefy during shaking but they do undergo settlement. Settlement of the ground surface also occurs for liquefied deposits. When small, these settlements may not be particularly evident but the presence of foundations on end bearing piles tends to make the settlement more apparent. A rather mild example of such settlement occurred at the site of the Bay Milk Company in Edgecumbe (Pender and Robertson [46]), a more significant example occurred in the South of Market area of San Francisco after the Loma Prieta event (Pender [48]), and very significant settlements were apparent at Port Island after the Kobe earthquake (Tokimatsu et al [62]).

\section{SHALLOW FOUNDATIONS}

Several aspects of the capacity of shallow foundation capacity under seismic loading have been investigated in the decade. Damage to shallow foundations in Kobe is reviewed by Matsui and Oda [38].

\section{Undrained response of shallow foundations in clay}

The response of shallow foundations in Mexico City to the Michoacan earthquake was reviewed by a range of workers in $[3,26,31,42]$. The failure of shallow foundations in Mexico City has generated a considerable amount of thorough research into the undrained bearing capacity of shallow foundations under seismic loading, Pecker et al $[23,44,45]$, and Faccioli and Paolucci [72]. The motivation for this work was to explain some of the foundation failures that occurred in Mexico City during the 1985 event and to assist with framing recommendations for foundation design section of Eurocode 8 [15]. These results have shown that the seismic bearing capacity is affected by the size of the foundation, decreasing as the foundation dimensions increase. Most significant, however, is the pre-earthquake static bearing capacity factor of safety. When this is excess of 2 it was concluded that inertia effects are not significant. They also concluded that the eccentricity of loading should not exceed $0.3 \mathrm{~B}$, a recommendation which appears in EC8.

\section{Drained response of shallow foundations}

The effect of horizontal acceleration on the drained bearing capacity of shallow foundations has been investigated by Richards et al [52, 57], Budhu et al [11, 12], Dormieux and Pecker [20], Sarma et al [53,54], and Ghahramani and Berrill [25]. These have produced diagrams showing how the bearing capacity factors $\mathrm{N}_{c}, \mathrm{~N}_{q}$ and $\mathrm{N}_{\gamma}$ are affected by horizontal and vertical accelerations. 


\section{Undrained response of shallow foundations in saturated sand}

This is a topic that is suffering from neglect. Too often the assumption is made that the behaviour will be drained because of the ability of sand to dissipate pore water pressures very rapidly. However, whether or not this is true will depend on the size of the foundation, with undrained behaviour being more likely for large foundations. As explained above, the distribution of the cyclic pore water pressure is complex. One could suggest that coming to an adequate solution for this case should be high on the list of geotechnical earthquake research priorities for the next decade.

\section{Seismic soil-structure interaction}

This topic has continued to be widely researched with many useful refinements of linear elastic soil structure interaction techniques presented. McKenzie and Pender [39] have proposed representative equivalent shear moduli values for foundations in clay as a function of earthquake peak ground acceleration

\section{DEEP FOUNDATIONS}

\section{Raked piles}

The Loma Prieta and Costa Rican earthquakes demonstrated again, what has been observed many times before, that raked piles are severely damaged during earthquake loading. The harbour structures in the Port of Oakland were reconstructed without raked piles. This is one solution which results in a structure with much greater lateral flexibility. The cause of much of the damage to raked piles is probably a consequence of older pile design methods which were based on a graphic statics approach to the load distribution. This fails to account for the significant effect raking has on the head stiffness of the piles. This increased stiffness means that the raked piles carry a large proportion of the lateral load. Design which accounts correctly for the lateral stiffness of the piles will give the correct actions at the pile head and avoid the problem.

Gapping

Gapping occurs near the ground surface between the shaft and surrounding soil of a cyclically loaded pile in clay. A clear example during the Loma Prieta earthquake is given by Pender [48]. Some progress has been made with modelling this process, Pender and Pranjoto [50], in which it was found that the effect of the gap is to reduce the lateral stiffness of the pile so that Winkler modelling should be based on springs on one side of the pile only.

\section{Kinematic interaction}

Kinematic interaction between a pile shaft and the surrounding soil means that the pile head motion is different from the free field motion. For flexible piles in uniform soils it has been found that the kinematic interaction effect is not great; Poulos and Tabesh [51] present recent results which confirm this conclusion. However, for piles in layered deposits it has been found that the sudden contrast in stiffness places severe demands in curvature on the pile shaft. Japanese experience, Pender [48], in excavating piles after earthquakes demonstrates this (although in one case the piles were not excavated until about 20 years after the earthquake, the structure having remained in service during this period). To date the majority of analysis of kinematic interaction has been based on linear elastic behaviour of the pile and surrounding soil. There is a need to extend this to include nonlinear behaviour and the effect of increasing pore water pressure in saturated sand.

\section{Damage to piles in liquefied soil}

The Kobe earthquake has produced considerable documentation of damage to piles passing through liquefied soil layers $[24,28$, 36, 43]. Christenssen and Berrill [18] examined the Landing Road bridge in Whakatane after the Edgecumbe earthquake and found indications of pile damage because lateral spreading of the river bank was inhibited by the bridge abutment.

\section{RETAINING STRUCTURES}

Damage to retaining walls has been observed in several of the earthquakes over the decade but none of these, with the exception of the walls in the Port of Kobe, have been a source of surprise. In the case of the caisson walls at Kobe, the failure is a very complex interaction; the problem may not be so much a consequence of earthquake generated earth pressures as more a matter of the failure of the foundations beneath the walls which lead to the accumulation of large permanent lateral and rotational displacements, Inagaki et al [30].

Earlier work for the elastic stiffness of shallow foundations and piles resulted in a series of simple formulae for the stiffness components. These are very useful because they enable one to use a spreadsheet or similar software to do parametric design studies. Similar formulae have been developed for the dynamic response of rigid retaining structures, Veletsos $[65,66]$.

\section{SLOPE STABILITY}

During the decade some slope instability was observed as a consequence of the earthquakes. Examples being superficial slumping of coastal cliffs in the Edgecumbe and Loma Prieta events and the reactivation of ancient landslides in Loma Prieta. In the case of Kobe there were more significant slope failures, Sassa et al [55]. However, for none of the earthquakes in the decade were slope stability effects of equal significance to the other types of damage.

\section{EARTH DAM RESPONSE}

The major effects associated with dams in the decade were the Matahina dam during the Edgecumbe earthquake and the San Fernando dams in Los Angeles in the Northridge event. Extensive damage was reported by Tani and Shiomi [60] for small earth dams in the Kobe earthquake.

Some slumping of the rock fill shoulder material of the Matahina dam was observed after the Edgecumbe earthquake. The dam also had enough instrumentation to allow modelling with a comparison of the recorded behaviour which showed that changes took place in the response of the dam during the course of the earthquake, McVerry [40]. It was found that the effective fundamental periods and damping of the dam were considerably larger in the main shock than in the principal foreshock that 
occurred 7 minutes earlier, or in a previous small earthquake recorded in 1977. The periods and damping then returned to their initial values as the motion decreased. The subsequent difficulties experienced by the dam and subsequent partial reconstruction were a consequence of unsatisfactory performance of the filters.

The San Fernando dams are a pair of hydraulic fill structures which were out of service at the time of the earthquake. Being so close to the epicentre they were subjected to large accelerations. Damage consisted of liquefaction, cracking and permanent displacements, Bardet and Davis [4]. These dams were also damaged in the 1971 San Fernando earthquake although then they were impounding water.

\section{CONCLUSIONS}

Steady progress has been made in many areas of earthquake geotechnical engineering in the decade. The stimulus for this has been the number of major earthquakes which have produced good quality data of ground response and foundation performance.

In the opinion of the author the major achievement in the geotechnical field in the decade has been clarification of the nature of nonlinear effects in site response.

Perhaps the most immediate topic that needs to be addressed in the future is the response of both shallow and deep foundations in saturated deposits of sand.

\section{REFERENCES}

1. Aki, K. \& Irikura, K. (1991) Characterisation and mapping of earthquake shaking for seismic zonation. Proc. 4th. International Conference on Seismic Zonation, Stanford. Vol. 1, pp. $61-110$

2. Aki, K. (1988) Local site effects on strong ground motion. Proc. ASCE Specialty Conf. Earthquake Engineering and Soil Dynamics II, pp. 103-155.

3. Auvinet, G., Pecker, A., and Salençon, J. (1996), Seismic bearing capacity of shallow foundations in Mexico City during the 1985 Michoacan earthquake, Eleventh World Conference on Earthquake Engineering, paper No. 1966.

4. Bardet, J P and Davis, C. A. (1996), Performance of the San Fernando dams during the 1994 Northridge earthquake, Journal of Geotechnical Engineering, Vol. 122, No. 8, pp 613-622.

5. Beresnev, I.A., Wen, K.L., and Yeh, Y.T. (1995), Nonlinear soil amplification: its corroboration in Taiwan, Bulletin of the Seismological Society of America, Vol. 85, No. 2, pp. 496-515.

6. Berrill, J.B. (1977), Site effects during the San Fernando California, earthquake. Proc. 6th. World Conf. on EQ Engineering, Vol. I, pp. 432-438.

7. Bolt, B. A. (1992), Earthquakes - a primer. $3^{\text {rd }}$ edition, Freeman.

8. Borcherdt, R D (1994), Estimates of site-dependent response spectra for design, Earthquake Spectra 10(4): 617-653.
9. Borcherdt, R. (1996), Strong Ground Motions Generated by the Northridge and Hanshin-Awaji earthquakes of January 17, 1994 and 1995; implications for site-specific design factors, Eleventh World Conference on Earthquake Engineering, paper No. 1246.

10. Borcherdt, R. D. (1996), Preliminary amplification estimates inferred from strong ground motion recordings of the Northridge earthquake of January 17, 1994, Proceedings of the International Workshop on Site Response subjected to Strong Earthquake Motions, Yokosuka, Japan. Edited by Sasumu Iai. Vol. 2, pp. 21-46.

11. Budhu, M., and Al-Karni, A. (1993), Discussion: Seismic bearing capacity of soils, Geotechnique 44 , No. 4, pp. 185 188.

12. Budhu, M., and Al-Karni, A. (1993), Technical note Seismic bearing capacity of soils, Geotechnique 43, No. 1, pp. 181-187.

13. Byau-Heng Chin and Keiiti Aki (1996), Local site effects study on ground motion during the Northridge earthquake, Proceedings of the International Workshop on Site Response subjected to Strong Earthquake Motions, Yokosuka, Japan. Edited by Sasumu Iai. Vol. 2, pp. 51-66.

14. Byrne, P M and McIntyre J (1994), Deformations in granular soils due to cyclic loading, Proc. Settlement ' 94 , ASCE Geotechnical Special Publication No. 40, Vol. 2, pp. 1864-1896.

15. CEN (European Committee for Standardisation) (1993). Structures in Seismic Regions - Design, Part 5: Foundations, Retaining Structures and Geotechnical Aspects. EUROCODE 8, Draft September (1993).

16. Chen, C.H., (1989), Degradation of Soil Stiffness in Lotung Experiments, Bulletin of the College of Engineering, N.T.U., No. 47, pp. 101-123.

17. Chin, B-Y, \& Aki, K. (1991), Simultaneous study of the source, path and site effects on strong ground motion during the 1989 Loma Prieta earthquake: a preliminary result on pervasive nonlinear site effects, Bull. Seis. Soc. of America, Vol. 81, No. 5, pp. 1859-1884

18. Christensen, S.A., and Berrill, J.B. (1994), Study of liquefaction in the 1987 Edgecumbe Earthquake : Landing Road bridge, NZNSEE Technical Conference and AGM, Taupo, March, pp. 150-157.

19. Darragh, R.B. \& Shakel, A.F. (1991) The site response of two rock and soil station pairs to strong and weak ground motion. Bull. Seis. Soc. of America, Vol. 81, No. 5, pp. 1885-1899.

20. Dormieux, L., and Pecker, A. (1995), Seismic bearing capacity of foundation on cohesionless soil, Journal of Geotechnical Engineering, Vol. 121, No. 3, Technical note no. 7286 .

21. Durward, J. A., Boore, D. M and Joyner, W. B (1996), The amplitude dependence of high frequency spectral decay: constraint on soil nonlinearity, Proceedings of the International Workshop on Site Response subjected to Strong Earthquake Motions, Yokosuka, Japan. Edited by Sasumu Iai. Vol. 2, pp. 82-103.

22. Elgamal, A.-W., Zeghal, M., Tang, H. T. and Stepp (1995), Lotung downhole array. I Evaluation of site dynamic properties, Journal Geotechnical Engineering, Vol. 121, No. 4, pp. 350-362. 
23. Faccioli, E., Paolucci, R., and Pecker, A. (1996), Codeoriented studies on the behaviour of shallow foundations under seismic loading, Eleventh World Conference on Earthquake Engineering, paper No. 2053.

24. Fujii, S., Funahara, H., and Yamaguchi, J. (1996), Numerical analysis of damaged piles due to soil liquefaction during Hyogoken-Nanbu earthquake, Eleventh World Conference on Earthquake Engineering, paper No. 329.

25. Ghahramani, A \& Berrill. J. B. (1995) Seismic bearing capacity factors by zero extension line method, Pacific Conference on Earthquake Engineering, Melbourne, Vol 3, pp. 147-156.

26. Girault, P. (1986), Analyses of foundation failures, Proc. Int. Conf. Sponsored by the Mexico section of the ASCE: The Mexico Earthquakes 1985 - Factors Involved and Lessons Learned, Mexico City, pp. 178-192.

27. Haines, A.J. (1993), Developments in computer modelling of microzonation effects, NZNSEE Technical Conference and AGM, Taupo, March, pp. 125-1133.

28. Hideto, S., Makoto, K., and Toshio, Y. (1996), Study on nonlinear dynamic analysis method of pile subjected to ground motion part 2: comparison between theory and experiment, Eleventh World Conference on Earthquake Engineering, paper No. 1289

29. Iai, S., Morita, T., Kameoka, T., Matsunaga, Y., and Abiko, K. (1995), Response of a dense sand deposit during 1993 Kushiro-Oki earthquake, Soils and Foundations, Vol. 35, No. 1, pp. 115-131

30. Inagaki, H., Iai, S., Sugano, T., Yamazaki, H. and Inatomi, T. (1996), Performance of caisson type quay walls at Kobe port, Soils and Foundations, Special Issue, January 1966, pp. 119-136.

31. Jaime, A, Rome, M P, and Resendiz, D, (1990), Behaviour of friction piles in Mexico City clay, Jnl. Geotech. Eng. 116(6): 915-931.

32. Jarpe, S. P., Hutchings, L. J., Hauk, T. F. \& Shakel, A. F. (1989), Selected strong and weak-motion data from the Loma Prieta earthquake sequence, Seismological Research Letters, Vol. 60 No. 4, pp. 167-176.

33. Liu, L and Dobry, R (1992), Centrifuge study of shallow foundations on saturated sand during earthquakes, Proc. 4th Japan - US Workshop on Earthquake Resistant Design of Lifeline Facilities and Countermeasures for Soil Liquefaction, Honolulu, Vol. 1, pp. 493-508.

34. Lo, R.C., Henderson, P.W., Morrison, K.I., and Finn, W.D.L. (1996), Seismic geotechnical considerations - an overview, Eleventh World Conference on Earthquake Engineering, paper No. 1853.

35. Loh, C., and Yeh, C. (1992), Field evaluation and site response identification at SMART-I site, Soil Dynamics and Earthquake Engineering 11, pp. 347-356.

36. Makoto, K., Toshio, Y., and Hideto, S (1996), Study on nonlinear dynamic analysis method of pile subjected to ground motion part 1: theory, Eleventh World Conference on Earthquake Engineering, paper No. 1167.

37. Martin, G. R. and Dobry, R. (1994), Earthquake site response and seismic code provisions, Bulletin of the United States National Centre for Research in Earthquake Engineering (NCEER), Buffalo, New York 8(4): 1-6.
38. Matsui, T. and Oda, K. (1996), Foundation damage of structures, Soils and Foundations, Special Issue, January 1966, pp. $189-200$

39. McKenzie, N. P., and Pender, M. J. (1996), Representative shear modulus for shallow foundation seismic soil-structure interaction, Proc. 11th. World Conference on Earthquake Engineering, Acapulco, paper 931

40. McVerry, G. H. (1987) Linear modal analysis of the response of Matahina dam in the Edgecumbe earthquake, Report EES199, Physics and Engineering Laboratory, DSIR.

41. McVerry, G. H. (1996), Microzone effects in Wellington, New Zealand demonstrated by records from a strong-motion array, Eleventh World Conference on Earthquake Engineering, paper No. 1234.

42. Mendoza, M. J and Auvinet, G (1988) The Mexico City earthquake of September 19,1985 - Behaviour of building foundations in Mexico City, Earthquake Spectra 4(4): 835. 853.

43. Mizuno, H., Iiba, M, and Hirade, T. (1996), Pile damage during 1995 Hyougoken-Nanbu earthquake in Japan, Eleventh World Conference on Earthquake Engineering, paper No. 977.

44. Pecker, A. and Salencon, J. (1991), Seismic bearing capacity of shallow foundations on clay soils, CENAPRED, Proc. International Workshop on Seismology and Earthquake Engineering, Mexico, pp. 287-304

45. Pecker, A. (1996), Seismic bearing capacity of shallow foundations, Eleventh World Conference on Earthquake Engineering, paper No. 2076.

46. Pender, M. J., and Robertson, T. W., (editors) (1987) Edgecumbe Earthquake: Reconnaissance Report, Bulletin of the N.Z. National Society for Earthquake Engineering, Vol 20, No.3, pp. 201-249. (Also published in: Earthquake Spectra, Vol. 3 No. 4 , pp. $659-745$.

47. Pender, M.J. (1992), Linear and nonlinear earthquake site response, Proc. Wroth Memorial Symposium, Oxford, Thomas Telford, pp. 406-419.

48. Pender, M J (1993). Aseismic pile foundation design analysis, Bulletin of the NZ National Society for Earthquake Engineering 26(1): 49-161.

49. Pender, M J (1995) Design of foundations to resist earthquake loading, Keynote address Pacific Conference on Earthquake Engineering, Melbourne, Vol 2, pp. 1-21.

50. Pender, M. J. and Pranjoto, S., (1996) Gapping effects during cyclic lateral loading of piles in clay, Proc. 11th. World Conference on Earthquake Engineering, Acapulco, paper 1007.

51. Poulos, H.G., and Tabesh, A. (1996), Seismic response of pile foundations - some important factors, Eleventh World Conference on Earthquake Engineering, paper No. 2085.

52. Richards, R., Elms, D.G., and Budhu, M. (1993), Seismic bearing capacity and settlements of foundations, Journal of Geotechnical Engineering, Vol. 119, No. 4, paper No. 661.

53. Sarma, S. K. and Iossifelis, I. S. (1990), Seismic bearing capacity of shallow strip footings, Geotechnique 40(2): 265 273

54. Sarma, S. K. (1996) Bearing capacity of strip footings near sloping ground during earthquakes, Proc. 11th. World Conference on Earthquake Engineering, Acapulco, paper 2078. 
55. Sassa, K., Fukuoka, H., Scarascia-Mugnozza, G., and Evans, S. (1996), Earthquake induced landslides: distribution, motion and mechanisms. Soils and Foundations, Special Issue, January 1966, pp. 99-107

56. Sato, K., Kokusho, T., Matsumoto, M., and Yamada, E. (1996), Nonlinear seismic response and soil property during strong motion. Soils and Foundations, Special Issue, January 1966, pp. 41-52.

57. Shi, X and Richards, R. (1995). Seismic bearing capacity with variable shear transfer, Bulletin NZ National Society for Earthquake Engineering 28(2): 153-163.

58. Somerville, P. (1996), Forward rupture directivity in the Kobe and Northridge earthquakes, and implications for structural engineering, Proceedings of the International Workshop on Site Response subjected to Strong Earthquake Motions, Yokosuka, Japan. Edited by Sasumu Iai. Vol. 2, pp. 324-342.

59. Taber, J.J. (1993), Instrumental recording of microzonation effects, NZNSEE Technical Conference and AGM, Taupo, March, pp. 119-124.

60. Tani, S. and Shiomi, T. (1996), Analysis of earth dam damages caused by the Hyogoken-nanbu earthquake, The 1995 Hyogoken-Nanbu earthquake, Committee on Earthquake Engineering, Japan Society of Civil Engineers, pp. 115-124.

61. Technical Committee for Earthquake Geotechnical Engineering, TC4, ISSMFE. (1993). Manual for Zonation on Seismic Geotechnical Hazards, Japanese Society for Soil Mechanics and Foundation Engineering.

62. Tokimatsu, K., Mizuno, H. and Kakurai, M. (1996) Building damage associated with geotechnical problems, Soils and Foundations, Special Issue, January 1966, pp. 219-234.

63. Tong, H., Ansary, M.A., and Yamazaki, F. (1996), Predominant period and non-linear response of soil layers from multiple-site records, Eleventh World Conference on Earthquake Engineering, paper No. 1077.

64. Van Dissen, R.J., Taber, J.J., Stephenson, W.R., Sritharan, S., Perrin, N.D., McVerry, G.H., Campbell, H.J., and Barker, P.R. (1993), Ground shaking hazard zonation for Wellington City and suburbs, New Zealand, NZNSEE Technical Conference and AGM, Taupo, March, pp. 134-141.
65. Veletsos, A N and Younan, A H (1994), Dynamic soil pressures on rigid vertical walls, Earthquake Engineering and Structural Dynamics 23: 275-301.

66. Veletsos, A N and Younan, A H (1994), Dynamic soil pressures on rigid cylindrical vaults, Earthquake Engineering and Structural Dynamics 23: 645-669.

67. Werner, S. D. and Dickenson, S. E. (1995), Hyogo-ken Nanbu earthquake of January 17, 1995: A post earthquake reconnaissance of port facilities. Report prepared for the Port of Los Angeles and the Port of Portland.

68. Whitman R.V. (1986), Are the soil conditions in Mexico City unique? Proc. International Conference on the Mexico City Earthquakes - 1985 Factors involved and lessons learnt. ASCE, pp. 163-177.

69. Yasuda, S., Ishihara, K., Harada, K., and Shinkawa, N. (1996), Effect of soil improvement on ground subsidence due to liquefaction, Soils and Foundations, Special Issue, January 1966, pp. 99-107.

70. Zeghal, M., Elgamal, A. -W., H. T. Tang and Stepp, J. C. (1995), Lotung downhole array. II: Evaluation of soil nonlinear properties, Journal of Geotechnical Engineering, Vol. 121, No. 4, pp. 363-378.

71. Zheng, J., Suzuki, K., Ohbo, N., and Prevost, J.H. (1996), Evaluation of sheet pile-ring countermeasure against liquefaction for oil tank site, Soil Dynamics and Earthquake Engineering 15, pp. 369-379.

72. Faccioli, E., Paolucci, R. (1966) Seismic behaviour and design of foundations and retaining structures, European Commission -"Human Capital and Mobility" programme. Prenomative Research in Support of Eurocode 8, report No. 2.

73. McVerry, G.H. (1997), Near-fault earthquake records and implications for design motions; Technical Conference and AGM, NZ National Society for Earthquake Engineering, Wairakei, pp. 88-95. 